\title{
Reexamination of the Near-Surface Airflow over the Antarctic Continent and Implications on Atmospheric Circulations at High Southern Latitudes*
}

\author{
THOMAS R. PARISH \\ Department of Atmospheric Science, University of Wyoming, Laramie, Wyoming \\ DAVID H. BROMWICH \\ Polar Meteorology Group, Byrd Polar Research Center, The Ohio State University, Columbus, Ohio
}

(Manuscript received 30 May 2006, in final form 11 August 2006)

\begin{abstract}
Previous work has shown that winds in the lower atmosphere over the Antarctic continent are among the most persistent on earth with directions coupled to the underlying ice topography. In 1987, Parish and Bromwich used a diagnostic model to depict details of the Antarctic near-surface airflow. A radially outward drainage pattern off the highest elevations of the ice sheets was displayed with wind speeds that generally increase from the high interior to the coast. These winds are often referred to as "katabatic," with the implication that they are driven by radiational cooling of near-surface air over the sloping ice terrain. It has been shown that the Antarctic orography constrains the low-level wind regime through other forcing mechanisms as well. Dynamics of the lower atmosphere have been investigated increasingly by the use of numerical models since the observational network over the Antarctic remains quite sparse. Real-time numerical weather prediction for the U.S. Antarctic Program has been ongoing since the 2000-01 austral summer season via the Antarctic Mesoscale Prediction System (AMPS). AMPS output, which is based on a polar optimized version of the fifth-generation Pennsylvania State University-National Center for Atmospheric Research Mesoscale Model, is used for a 1-yr period from June 2003 to May 2004 to investigate the mean annual and seasonal airflow patterns over the Antarctic continent to compare with previous streamline depictions. Divergent outflow from atop the continental interior implies that subsidence must exist over the continent and a direct thermal circulation over the high southern latitudes results. Estimates of the north-south mass fluxes are obtained from the mean airflow patterns to infer the influence of the elevated ice sheets on the mean meridional circulation over Antarctica.
\end{abstract}

\section{Introduction}

Low-level winds are among the most spectacular meteorological features of the Antarctic. Numerous studies of the low-level Antarctic wind field have been conducted since the time of the earliest explorations onto the face of the continent. Primary characteristics of the surface wind include speeds that are proportional to the slope of the underlying ice terrain and wind directions that are linked to the orientation of the gradient of the

* Byrd Polar Research Center Contribution Number 1342.

Corresponding author address: Thomas R. Parish, Department of Atmospheric Science, University of Wyoming, Laramie, WY 82071.

E-mail: parish@uwyo.edu

DOI: $10.1175 / M W R 3374.1$

(C) 2007 American Meteorological Society ice terrain (e.g., Ball 1960; Parish and Bromwich 1987). The term "katabatic" is often used when discussing Antarctic low-level winds. Mean wind speeds and directions from records of manned and automatic weather stations are consistent with that description. Parish and Cassano (2003) have shown, however, that katabatic forcing is considerably weaker during the summer period from December to February over nearly the entire continent and propose that blocking effects by the Antarctic terrain and the resulting ambient pressure gradient force in the atmosphere are responsible for establishing a wind regime qualitatively similar to that produced by diabatic cooling of the terrain slopes. They note that wind speed and direction are insufficient to determine whether a flow regime is classified as katabatic.

Figure 1 serves to illustrate the key geographical features of the Antarctic continent and high southern lati- 


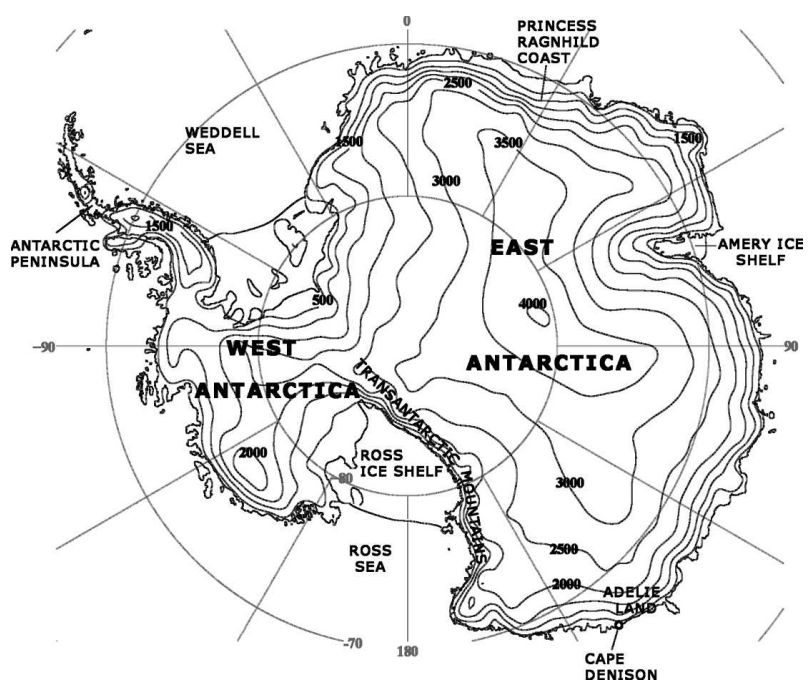

FIG. 1. The Antarctic continent with terrain contours (m).

tudes. The Antarctic ice sheets consist of a broad, elevated ice plateau inland from the coast. Terrain slopes increase from the high interior of both East and West Antarctica to the coast. Mather and Miller (1966) first estimated the mean airflow at the surface over Antarctica, depicting a radially outward drainage off the high plateau of East Antarctica. At the time of the Mather and Miller streamline map, the large-scale terrain over the East Antarctic ice sheet had not been mapped. The Mather and Miller streamlines, however, successfully represented the broad-scale surface airflow patterns. By the 1970s, detailed mapping of the continent had been completed. Parish and Bromwich (1987) used the diagnostic model of Ball (1960) to infer the mean wintertime streamlines of the surface wind field over the high-resolution ice terrain. Figure 2 is a modified version of that presented in Parish and Bromwich (1987) that is based on a $50-\mathrm{km}$ horizontal spacing. Zones of streamline convergence or "confluence zones" can be identified about the continent, most prominently onto the Amery Ice Shelf at $70^{\circ} \mathrm{E}$, near Adélie Land at $142^{\circ} \mathrm{E}$, and the broad region upslope from the Ross Ice Shelf. Validation of the Parish and Bromwich streamline map has been made with available observations and aeolian snow features called sastrugi that are oriented in the direction of the mean wind. The purpose of this paper is compare more recent results on the Antarctic wind field with those presented in Parish and Bromwich (1987) and to infer the implications of the Antarctic low-level wind regime on flow characteristics over the high southern latitudes.

During the past $20 \mathrm{yr}$, extensive efforts have been made in simulating Antarctic winds using mesoscale models (e.g., Parish and Waight 1987; Hines et al. 1995; Gallée et al. 1996; Heinemann 1997). More recently, a

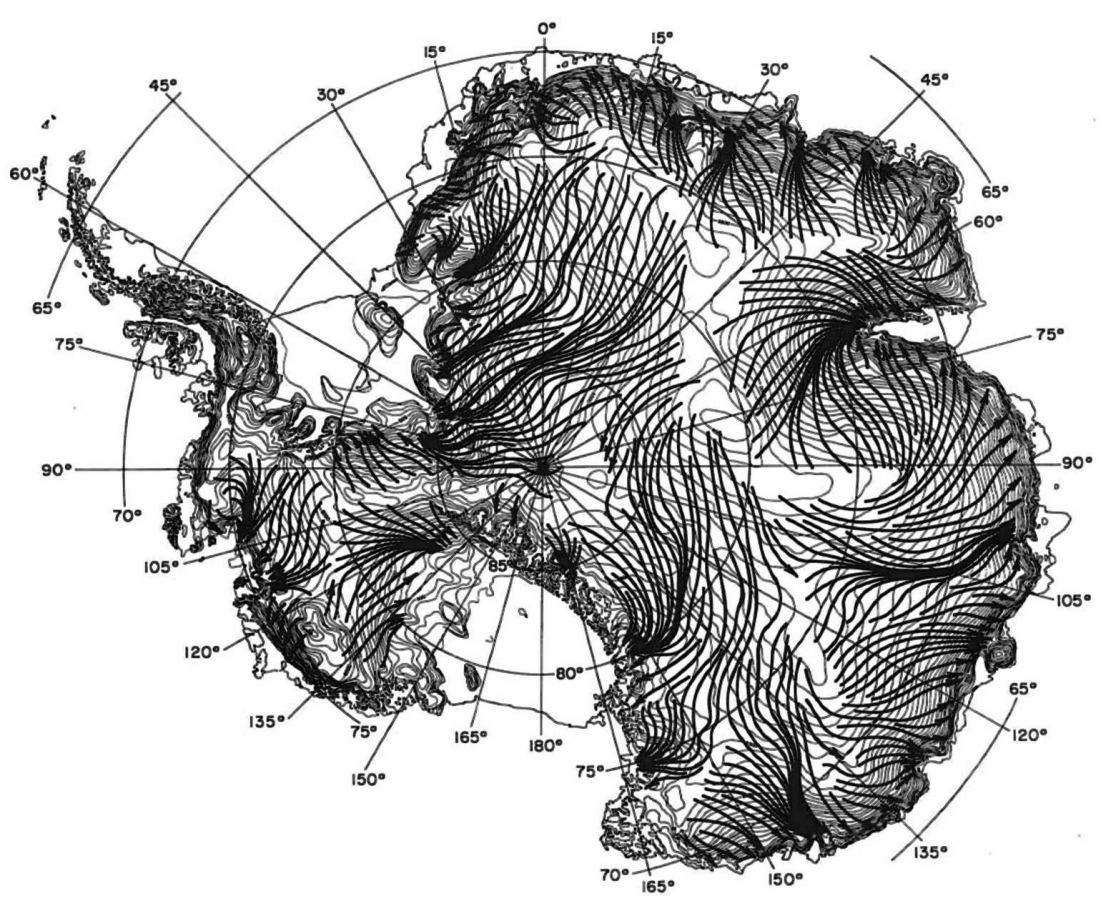

FIG. 2. Mean wintertime streamlines over the surface of the Antarctic continent (adapted from Parish and Bromwich 1987). 
polar optimized version of the fifth-generation Pennsylvania State University-National Center for Atmospheric Research (NCAR) Mesoscale Model (MM5), also referred to as Polar MM5, has been used for realtime numerical simulations. A number of physical parameterization schemes for the surface and radiative properties required modification from the original MM5 system (e.g., Bromwich et al. 2001; Cassano et al. 2001; Guo et al. 2003). The first real-time forecasts for the U.S. Antarctic Program were produced at the Byrd Polar Research Center at the Ohio State University in 1999. Concurrent modeling efforts were also conducted by the Australian Bureau of Meteorology using the Antarctic Limited Area Prediction System (Adams 2005). Validation of the numerical products from MM5 has been conducted by Bromwich et al. (2001, 2003, 2005), Cassano et al. (2001), Guo et al. (2003), and Monaghan et al. (2003). The importance of such numerical products for logistical operations became obvious and in September 2000 the Antarctic Mesoscale Prediction System (AMPS), a collaborative effort between NCAR and the Byrd Polar Research Center, began producing numerical forecasts using a triply nested grid of 90-, 30-, and 10-km horizontal resolution (Powerset al. 2003). The 30-km domain covers the entire Antarctic continent, providing sufficient horizontal resolution to capture detailed topographic forcing over nearly the entire continent, with the exception of highly complex terrain such as along the Transantarctic Mountains.

Streamline maps and other analyses shown here are taken from the $30-\mathrm{km}$ horizontal resolution grids for the 1-yr period from 1 June 2003 to 31 May 2004. The 90-km domain from the same period has also been used in an attempt to infer the impact of the Antarctic topography and local airflow on the mean circulation between polar latitudes and midlatitudes of the Southern Hemisphere. This period was chosen to maintain a consistent grid structure, as the configuration of the nested grids in AMPS changed in May 2003. This study will also address the topographic constraints arising from the elevated Antarctic ice sheets on the mean atmospheric circulations. Low-level northward mass transport from Antarctica and the resulting mean meridional circulation over the high southern latitudes will also be examined. Such features were discussed only in a qualitative manner at the time of the Parish and Bromwich (1987) paper.

\section{Streamlines of the Antarctic wind field}

Streamlines inferred from the vector average wind directions estimated from the model of Ball (1960) are shown in Fig. 2. These streamlines represent wintertime conditions over the surface of Antarctica for which the katabatic wind is presumed to be active. Calculations are made assuming that the primary forcing is from diabatic cooling of the Antarctic ice slopes. The Ball (1960) model assumes a force balance in the lower atmosphere between the sloped-inversion horizontal pressure gradient, Coriolis, and friction forces. A grid spacing of $50 \mathrm{~km}$ was used in this analysis and no explicit forcing from effects of the large-scale ambient environment was included.

By comparison, Fig. 3 shows streamlines of the mean wind field at the lowest sigma level $(\sigma=0.9983$, approximately $13 \mathrm{~m}$ AGL at sea level and $7 \mathrm{~m}$ AGL over the high interior of Antarctica) from the $30-\mathrm{km}$ resolution AMPS archive for the 1-yr period of June 2003May 2004. Averages have been computed from the 3-hourly model output for each day of the record. In contrast to Fig. 2, this annual representation includes the impacts of synoptic forcing. The large-scale AMPS airflow pattern is radially divergent off the elevated East Antarctic ice sheet, similar to that shown in Fig. 2. Close inspection of individual streamlines from each of the two maps suggests similar paths of the mean airflow from the continental interior to the coast. Areas of streamline confluence about the coastal perimeter shown in Fig. 2 such as into the Amery Ice Shelf, upslope from Adélie Land, and onto the Ross Ice Shelf are portrayed in Fig. 3. Numerous other confluence regions can be seen about the continental rim in Fig. 3. It can be stated with confidence that the mean surface circulation over the Antarctic continent as represented by AMPS fits closely with the streamline map proposed by Parish and Bromwich (1987). The results shown in Fig. 3 are not sensitive to the particular year of the AMPS archive chosen. Similar patterns can be seen in wind records of previous years (Parish and Cassano 2003) as well as from the Ohio State version of the Polar MM5 that uses a $60-\mathrm{km}$ grid resolution over the Antarctic for 1993 (Guo et al. 2003). Results from the previous modeling work of Parish and Bromwich (1991) and the Regional Atmospheric Climate Model (van Lipzig et al. 2004) also show similar features.

It is apparent from the streamline patterns illustrated in Figs. 2 and 3 that the volume of air that moves off the high interior toward the coastal margin displays significant spatial variability. Parish and Bromwich (1987) noted that extraordinarily strong surface wind regimes are situated within the numerous confluence zones displayed on the streamline map. They argued that the confluence zone represents an enhancement of the cold air reserves upwind and hence stronger-than-average katabatic winds near the coast will result. Mean annual 


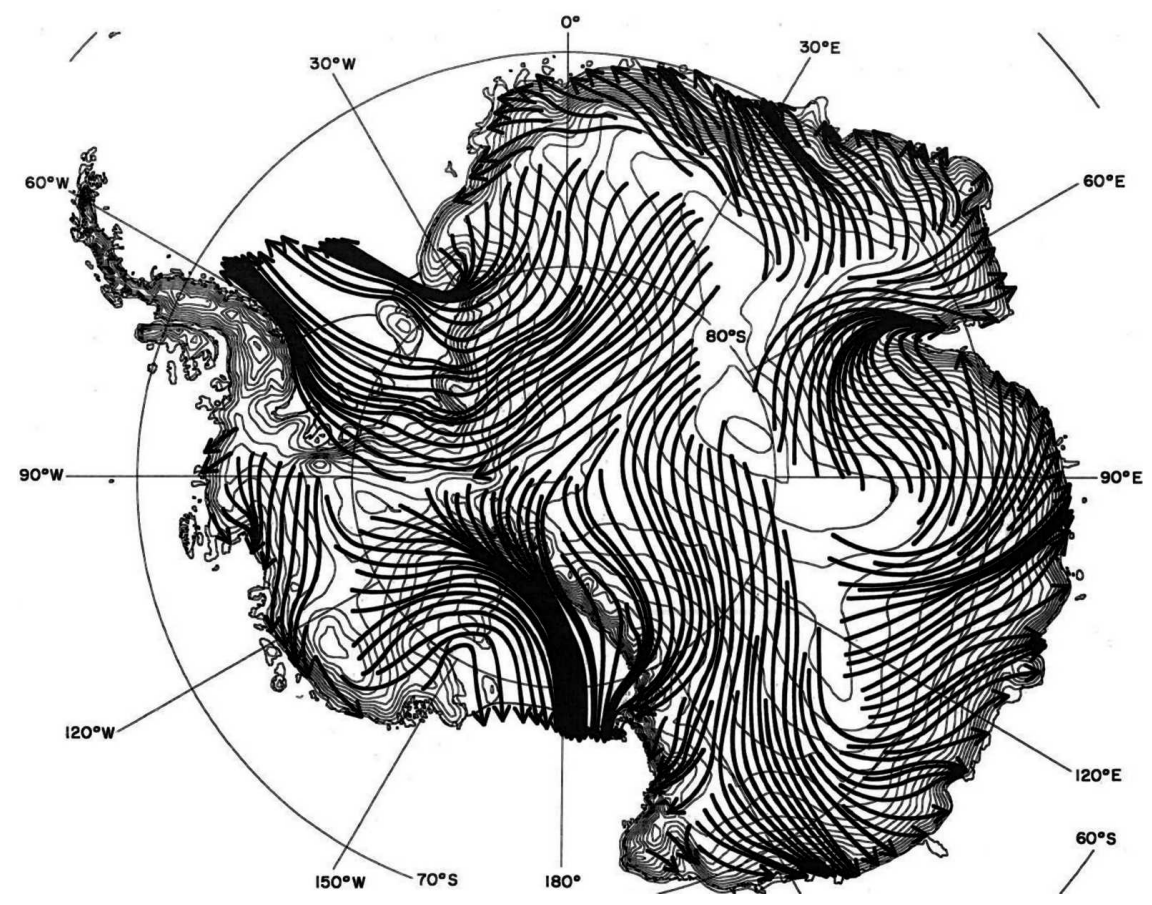

FIG. 3. Mean streamlines at $\sigma=0.9983$ over Antarctica from the June 2003-May 2004 AMPS archive.

wind speeds over the entire continent from the $30-\mathrm{km}$ resolution 2003 AMPS simulations at the $\sigma=0.9856$ level, corresponding to a height of approximately $100 \mathrm{~m}$ above the surface (Fig. 4), are testimony to the extreme windiness of the coastal sections of Antarctica. There is a clear topographic relationship in the wind speed patterns shown in Fig. 4 with the weakest winds over the gently sloping high interior and the strongest winds over the steep coastal ice slopes. Regions of localized wind maxima approaching $20 \mathrm{~m} \mathrm{~s}^{-1}$ are found downstream of the prominent confluence zones depicted in Figs. 2 and 3 at Adélie Land and to the west of the Amery Ice Shelf as well as along the Princess Ragnhild Coast, situated along the coast of East Antarctica from $25^{\circ}$ to $30^{\circ} \mathrm{E}$. Other maxima are seen along the coastal regions upslope from the eastern region of the Ross Ice Shelf and along a broad section of the East Antarctic coast near $90^{\circ} \mathrm{E}$. Most of these time-averaged annual wind speed maxima are tied to confluence zones represented in streamline maps and are thus thought to contain significant katabatic forcing. Although limited observational evidence exists regarding wind speeds over the continent, it is thought that the wind speeds shown are not unreasonable. Guo et al. (2003) have examined surface winds from the Polar MM5 and compared them with available data from an automatic weather station (AWS) and manned stations and conclude that wind speeds are simulated with "reasonable accuracy." Parish and Walker (2006) demonstrate that Polar MM5 wind speed simulations along Adélie Land compare well to the time-averaged historical observations.

Although most emphasis regarding Antarctic winds has been placed on the near-surface conditions, it is appropriate to inquire as to how the wind changes with height. From thermal wind considerations, the atmosphere adjacent to the elevated Antarctic ice sheets represents a cold core high pressure regime, reminiscent of the "glacial anticyclone" model proposed by Hobbs nearly a century ago (Court 1951). The attendant horizontal temperature gradients support the transition to a cyclonic circulation at upper levels of the troposphere and streamlines must undergo a rapid transition in the vertical over Antarctica. Vertical profiles of wind speed and wind direction show this. Figure 5a illustrates the wind speed profile at $67.5^{\circ} \mathrm{S}, 140^{\circ} \mathrm{E}$ situated near Adélie Land and at $72.5^{\circ} \mathrm{S}, 25^{\circ} \mathrm{E}$ corresponding to the wind maximum near Princess Ragnhild Coast from the AMPS archive. Both profiles suggest that maximum winds are found in the lowest 100-200 m and the entire depth of the katabatic wind layer is on the order of $1000 \mathrm{~m}$ or less. Maximum winds at both sites are roughly $50 \%$ stronger than winds just above the surface. Wind directions (Fig. 5b) at Adélie Land suggest that winds become westerly at about $2000 \mathrm{~m}$ above the ice surface. Along Princess Ragnhild Coast, wind 


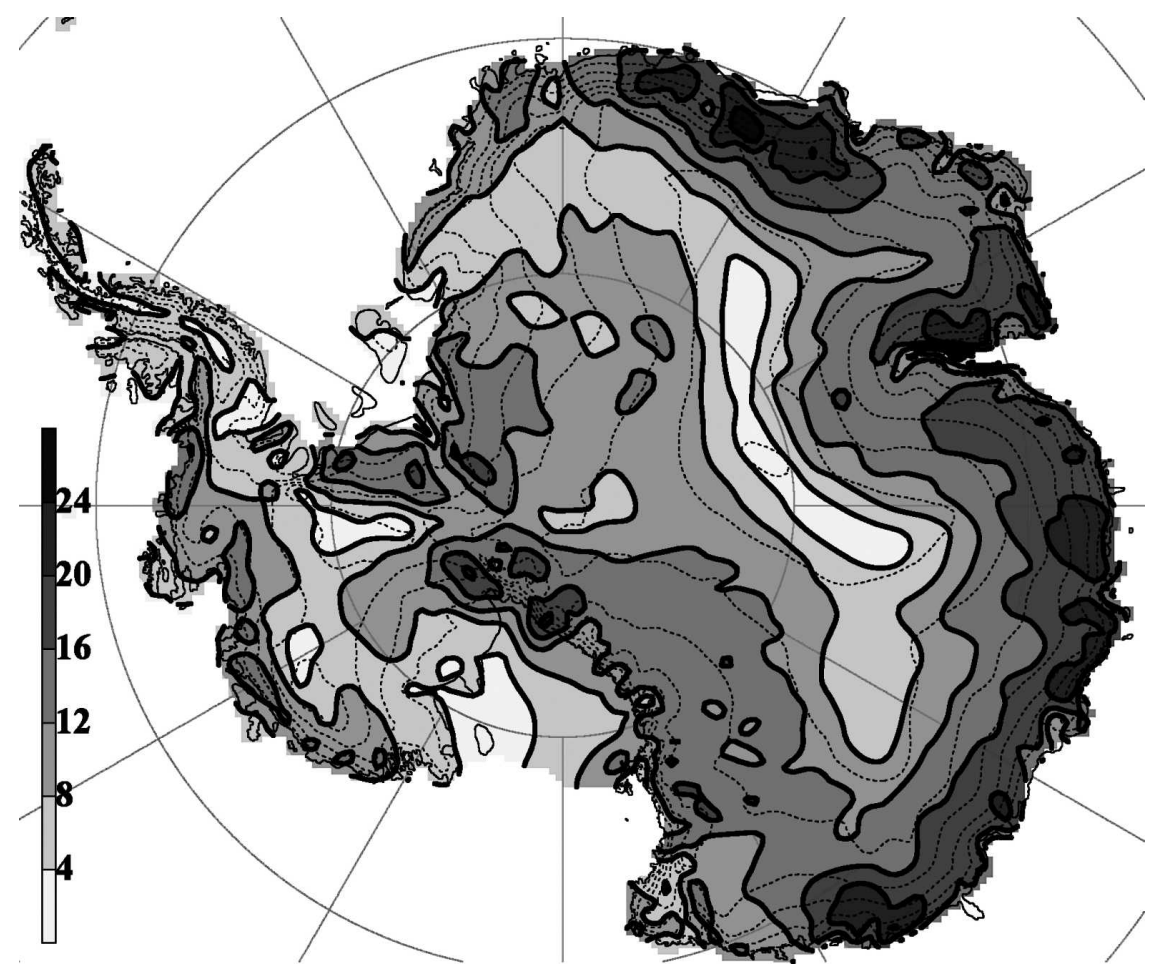

FIG. 4. Mean wind speed at $\sigma=0.9856$ from the June 2003-May 2004 AMPS archive.

directions remain easterly (although wind speeds are weak) until nearly $5000 \mathrm{~m}$ above the surface in conjunction with an offshore cyclone in the circumpolar trough. Vertical profiles for wind speeds at interior sites (not shown) are similar to that shown in Fig. 5a except for weaker maximum winds as shown in Fig. 4 and a shallower katabatic layer depth.

Figure 6 shows the streamlines of the wind field over a)

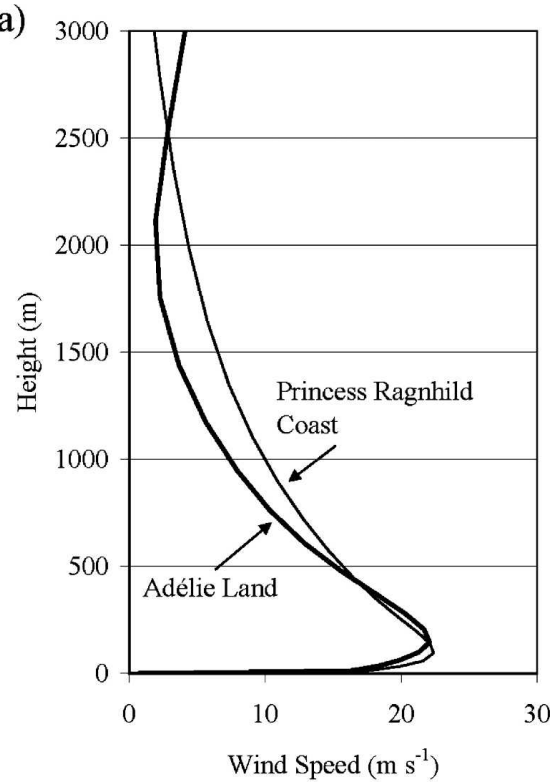

b)

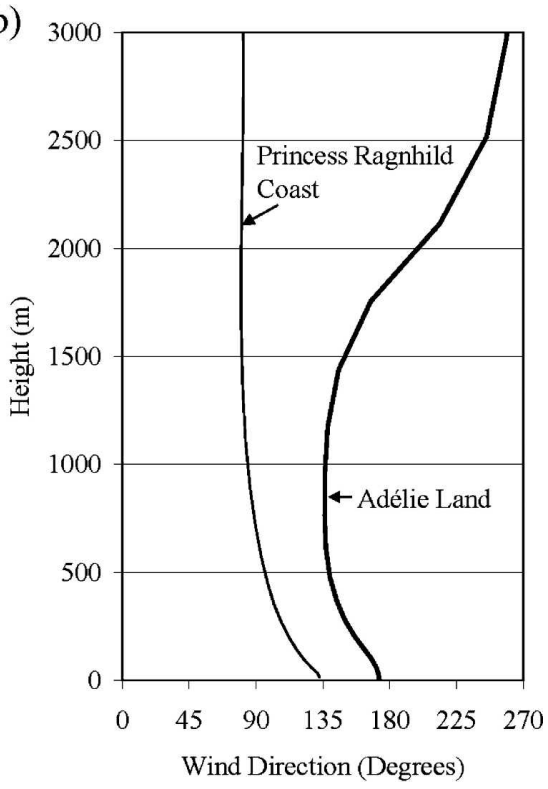

FIG. 5. Vertical profiles of (a) mean wind speed $\left(\mathrm{m} \mathrm{s}^{-1}\right)$ and (b) vector-averaged wind direction at $67.5^{\circ} \mathrm{S}, 140^{\circ} \mathrm{E}$ (Adélie Land) and $72.5^{\circ} \mathrm{S}, 25^{\circ} \mathrm{E}$ (Princess Ragnhild Coast) from the June 2003-May 2004 AMPS archive. 

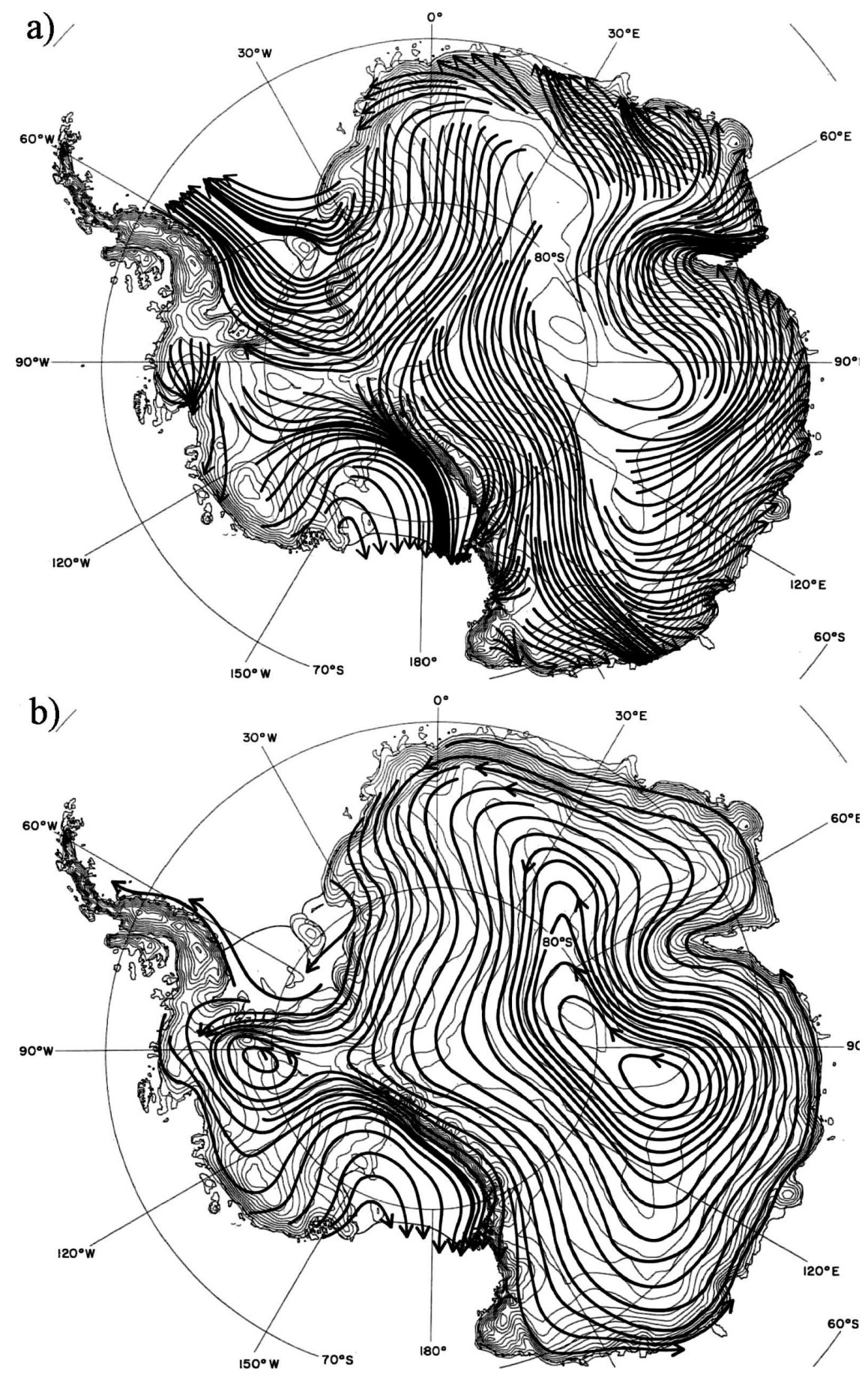

FIG. 6. Mean streamlines over Antarctica at (a) $\sigma=0.9856$ (approximately $100 \mathrm{~m}$ AGL) and (b) $\sigma=0.9344$ (500 m AGL) from the June 2003-May 2004 AMPS archive.

Antarctica at sigma levels corresponding to elevations approximately 100 and $500 \mathrm{~m}$ above the ice sheet from the 30-km resolution AMPS June 2003-May 2004 archive. By comparison with Fig. 3, only minor changes in the lowest 100-m streamline patterns can be seen in Fig. 6a. Wind speeds reach a maximum near this level (Fig. 5). By $500 \mathrm{~m}$ above the ice sheet (Fig. 6b), streamlines show significant changes from those at the surface and are directed nearly parallel to the terrain. Note that the streamlines trace out an anticyclonic vortex that mir- 
rors the high-interior topographic contours. The horizontal pressure gradients within the lowest $500 \mathrm{~m}$ above the surface must follow the gradient of the ice terrain to produce this streamline pattern. Analyses such as shown in Parish and Cassano (2003) and soundings taken over the continent reveal that the depth of the katabatic layer is typically $500 \mathrm{~m}$ or less, especially away from the steep coastal slopes. This suggests that the ambient horizontal pressure field at $500 \mathrm{~m}$ above the ice surface is not necessarily the result of radiative cooling but may be modulated by the Antarctic ice terrain through other processes such as blocking and adjustment.

The transition from an anticylonic circulation to a cyclonic vortex begins approximately $2000 \mathrm{~m}$ above the ice surface. By 5000 m (not shown), a cyclonic circulation is well established with the center of circulation over the Ross Sea, similar to the mean 500-hPa height contours shown in King and Turner (1997). Antarctic topography constrains the atmospheric motion over the continent throughout the entire tropospheric column. Radiation budgets associated with the elevated, sloping Antarctic ice sheets ensure that strong horizontal temperature gradients extend nearly to $600 \mathrm{hPa}$ over the highest portion of East Antarctica. A consequence of this topographic constraint is a stable circumpolar vortex in the upper troposphere, which does not show the variability of its Northern Hemisphere counterpart (Schwerdtfeger 1984).

Given the strong influence of the cold, elevated Antarctic ice sheets on the tropospheric circulations, it is reasonable to ask what seasonal variations are seen in the streamline patterns. A somewhat puzzling observation from the record of available observations at manned stations on the continent is that the mean summertime wind direction differs only slightly from that observed during winter. The detailed wind record for the historic Cape Denison station, situated at the steep coast of the continent at $67.1^{\circ} \mathrm{S}, 143^{\circ} \mathrm{E}$, is one such example. This record consists of surface wind observations taken hourly for the period of February 1912 through December 1913 during Douglas Mawson's Australasian Antarctic expedition from 1911 to 1914. Resultant wind data were computed for the six midwinter months [June, July, and August (JJA) of each year] and five summer months [December, January, and February (DJF)] of the 2-yr period. Mean wind speeds show a strong seasonal influence with winter wind speeds of $21.6 \mathrm{~m} \mathrm{~s}^{-1}$ and summer wind speeds of 13.7 $\mathrm{m} \mathrm{s}^{-1}$. Wind direction and wind constancy (a ratio of vector resultant wind speed to the mean wind speed), however, show little seasonal variation. The Cape Denison resultant wind direction is $162^{\circ}$ during winter and $156^{\circ}$ during summer; wind constancy is 0.96 for each period. Keller et al. (1994) have computed similar values from data collected by an AWS that was deployed at the Cape Denison site.

Figure 7 shows the mean streamlines at the lowest sigma level and wind speeds at the $\sigma=0.9856$ level from the $30-\mathrm{km}$ resolution AMPS archive for the winter period of JJA 2003 and for the summertime months of DJF 2003/04. The large-scale streamline patterns over Antarctica are nearly identical to those in Fig. 3 and show almost negligible seasonal modulation. Close inspection reveals similar streamline confluence features and drainage pathways off the interior of the East Antarctic ice sheet. Wind speeds, however, show considerable seasonal differences. Maximum wind speeds during winter are found near the coast of East Antarctica and reach nearly $30 \mathrm{~m} \mathrm{~s}^{-1}$ as compared with less than 20 $\mathrm{m} \mathrm{s}^{-1}$ during summer. The locations of the wind maxima persist throughout the year.

\section{Implications of the Antarctic wind field}

Because strong control of the atmospheric circulation in the lower levels is provided by the ice topography as shown in Fig. 3, it seems apparent that the mean northward low-level mass transport to and from the Antarctic continent must show significant longitudinal variation that is tied to the topography. Boundary layer mass transports must be considered semipermanent features owing to the prominent topographic pathways and constancy of the wind. Low-level exchanges of mass between the high southern latitudes and the rest of the atmosphere are thus concentrated in a few locations. To address this, the net mass flux in the lower atmosphere was determined using the annual averages in wind and temperature. Figure 8 depicts the integrated meridional mass flux in the lowest $1500 \mathrm{~m}$ at $2.5^{\circ}$ longitude increments along $70^{\circ} \mathrm{S}$ from the $30-\mathrm{km}$ AMPS archive. Recognizing the asymmetry of the Antarctic ice sheets about the pole, mass fluxes were also calculated at $67.5^{\circ} \mathrm{S}$ along the East Antarctic coast from $40^{\circ}$ to $160^{\circ} \mathrm{E}$. Regions of primary northward mass transports include the Amery Ice Shelf region near $70^{\circ} \mathrm{E}$, Adélie Land at $145^{\circ} \mathrm{E}$, the eastern side of the Transantarctic Mountains at $175^{\circ} \mathrm{E}$, and the eastern side of the Antarctic Peninsula at approximately $300^{\circ}$ E. Secondary maxima can be identified that are also associated with streamline confluence features. Prominent southward transport zones near $30^{\circ}, 40^{\circ}, 80^{\circ}$, and $290^{\circ} \mathrm{E}$ coincide with locations where the terrain departs markedly from zonal symmetry. Overall, visual inspection of the curves in Fig. 8 confirms that a net northward mass flux off the Antarctic ice sheets occurs in the lowest $1500 \mathrm{~m}$ that 

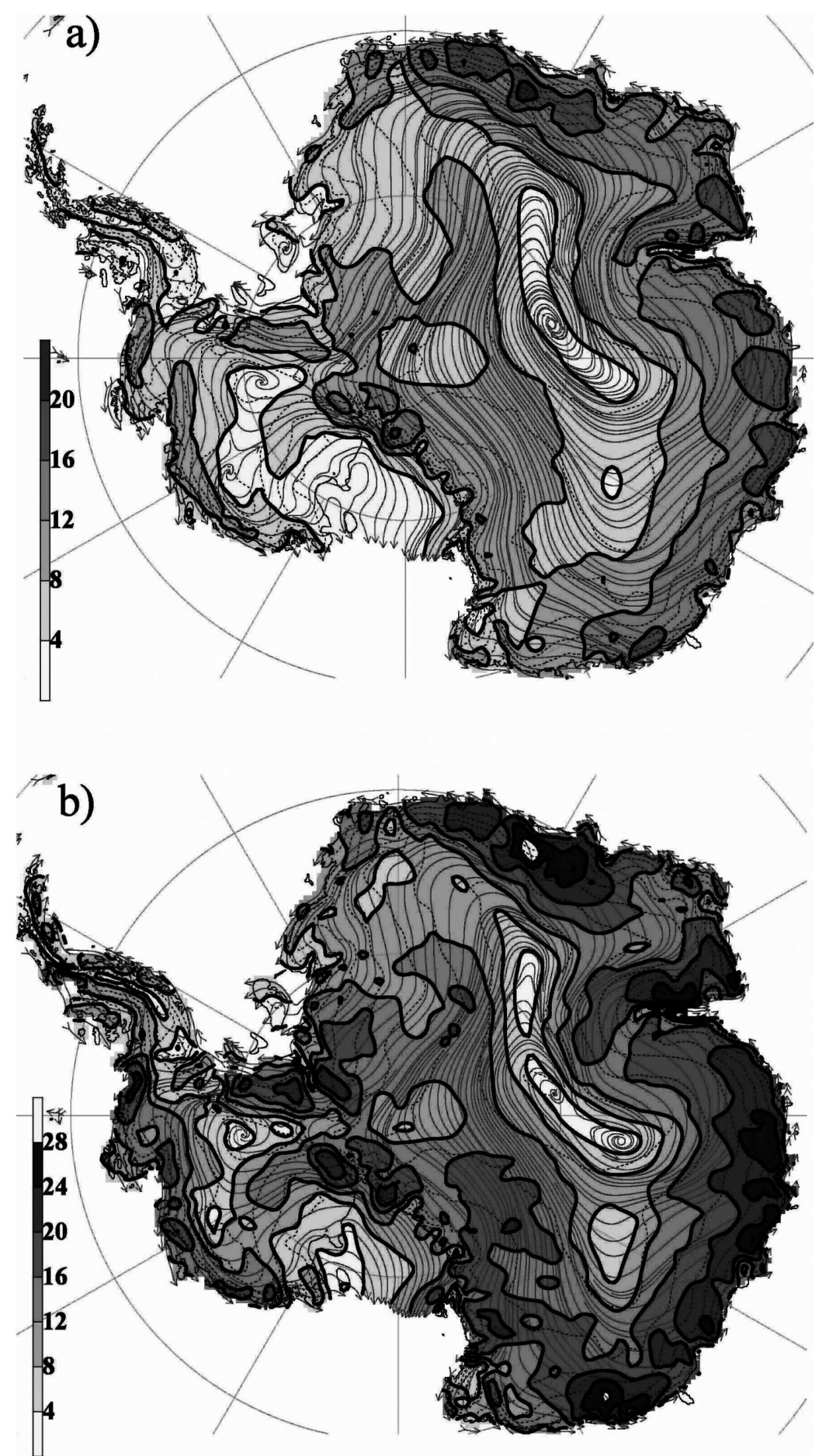

FIG. 7. Mean wind speeds $\left(\mathrm{m} \mathrm{s}^{-1}\right)$ and streamlines over Antarctica at $\sigma=0.9856$ (approximately $100 \mathrm{~m}$ AGL) for (a) the summertime period of DJF 2003/04 and (b) the wintertime period of JJA 2003 from the June 2003-May 2004 AMPS archive.

can be confirmed from the AMPS archive as discussed below.

Continuity requirements dictate that the timeaveraged divergent low-level transport off Antarctica is compensated for in part by a convergent upper-level transport directed southward toward the continent. To complete the thermally direct circulation, subsidence must occur over the continent with rising motion situ- 


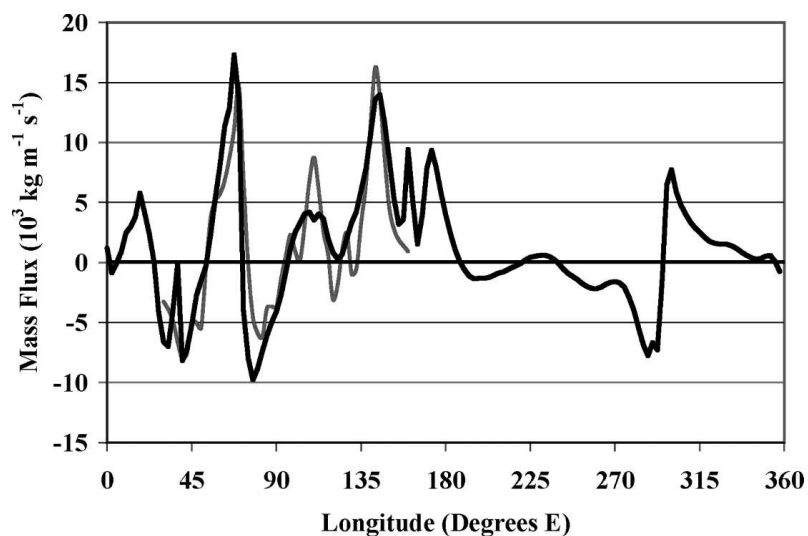

FIG. 8. Mean meridional mass flux (northward is positive) in lowest $1500 \mathrm{~m} \mathrm{AGL}$ at $67.5^{\circ} \mathrm{S}$ (thin line) and $70^{\circ} \mathrm{S}$ (thick line) from the June 2003-May 2004 AMPS archive.

ated to the north of the coastline. To depict the mean meridional circulation between the Antarctic and midlatitudes of the Southern Hemisphere, the 90-kmresolution outer AMPS domain was required. This domain extends to approximately $45^{\circ} \mathrm{S}$ and thus can capture the mean circulation that extends into the midlatitudes. The zonally averaged mean meridional circulation from the $90-\mathrm{km}$ grid for June 2003 to May 2004 is shown in Fig. 9. Qualitatively, subsidence over Antarctica feeds the drainage flows in the lower boundary layer. Near the katabatic-prone coastal sections, the strongest vertical velocities are found just above the boundary layer in response to the strong downslope flows. North of the Antarctic coastline, convergence results as the low-level winds decelerate offshore and rapidly become enveloped within the broad easterly circumpolar flow that surrounds the continent. Rising motion occurs with the largest values found just north of the coastline. Significant rising motions extend from the coast to the position of the mean circumpolar trough of low pressure between $60^{\circ}$ and $65^{\circ} \mathrm{S}$. Maximum rising motion is found in the lowest $1000 \mathrm{~m}$ near the continental margins but the height of the maximum vertical velocity increases to the north. This suggests that the primary forcing is from low-level processes such as the convergence of the drainage flows near the continental margin. Cyclone activity becomes of increasing importance north of the continent near the circumpolar trough axis in conjunction with the thermally indirect Ferrel cell.

The annual cycle of the low-level wind regime leads to pronounced seasonal modulations of the surface pressure (e.g., Parish and Bromwich 1997). Transition periods from winter to summer (August-December) and summer to winter (December-April) are the times of the most significant change in the wind, temperature,

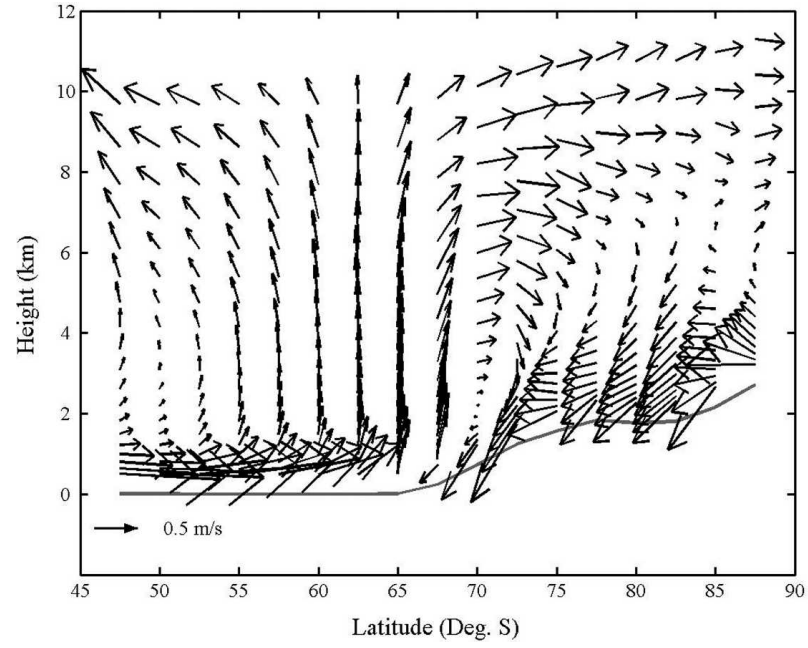

FIG. 9. Zonally averaged mean meridional circulation from the 90-km outer domain of the June 2003-May 2004 AMPS archive. Vertical velocities scaled by 100 .

and pressure fields. Modulation of the mean circulation must result. As the continent cools, drainage flows intensify and northward low-level mass fluxes from Antarctica increase as seen in Fig. 7. Surface pressures decrease over the continent with corresponding mass loading at midlatitudes of the Southern Hemisphere.

As evidence, Fig. 10a illustrates the monthly averages of the zonally averaged surface pressure deviations from the annual zonal mean at $50^{\circ}, 60^{\circ}, 70^{\circ}$, and $80^{\circ} \mathrm{S}$ from the $90-\mathrm{km}$ resolution 1-yr AMPS archive. Seasonal surface pressure changes display marked differences with latitude with the greatest amplitudes over Antarctica. During the austral autumn months, pressures over the continent, represented by zonal averages at $80^{\circ}$ and $70^{\circ} \mathrm{S}$, decrease rapidly over the Antarctic continent in response to surface cooling. Pressures then level off in April and May and actually increase in June before the primary minimum is reached in August. To the north of the continent near $50^{\circ} \mathrm{S}$, surface pressures display little evidence of an annual cycle. The semiannual component of atmospheric pressure change over Antarctica is thought to be forced by differential cooling and heating rates at $50^{\circ}$ and $65^{\circ} \mathrm{S}$ (e.g., Meehl 1991). Seasonal modulation of pressure over Antarctica and the high southern latitudes is also depicted in Fig. 10b, which shows the zonally averaged deviations in surface pressure as a function of latitude from the annual mean for the months of December and August. The summertime mass loading and wintertime mass transport away from Antarctica are clearly revealed with an annual cycle of surface pressures in excess of $20 \mathrm{hPa}$ over the high interior. Figure 11 illustrates the seasonal surface pressure change from August to December 2003 to 
a)

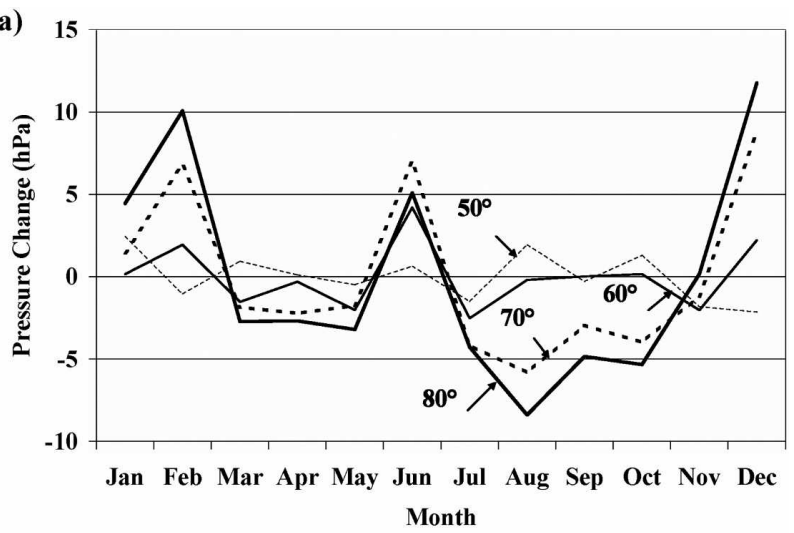

b)

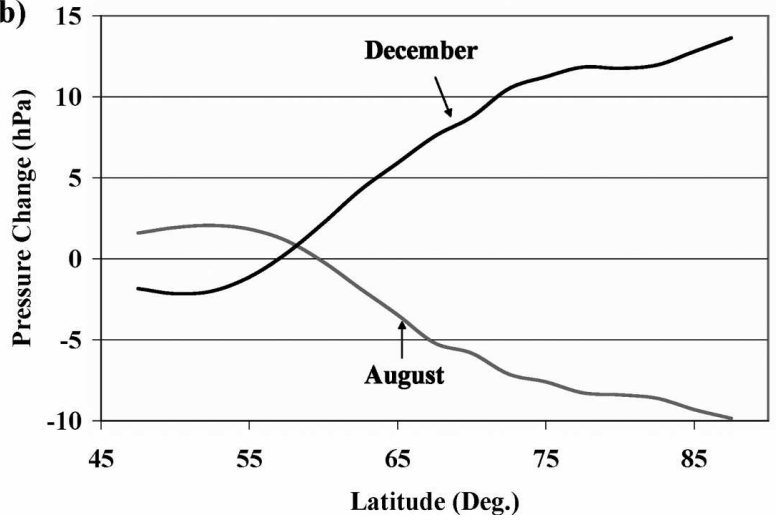

FIG. 10. (a) Annual course of zonally averaged surface pressure deviations from the annual mean $(\mathrm{hPa})$ for $50^{\circ} \mathrm{S}$ (thin, dashed line), $60^{\circ} \mathrm{S}$ (thin, solid line), $70^{\circ} \mathrm{S}$ (boldface, dashed line), and $80^{\circ} \mathrm{S}$ (boldface, solid line) latitudes. (b) Deviations in zonally averaged surface pressure from the annual average $(\mathrm{hPa})$ for December (thick line) and August (light line) with latitude corresponding to periods of highest and lowest surface pressure over Antarctica from the 90-km resolution June 2003-May 2004 AMPS archive.

show the summertime mass loading in response to the heating of the elevated continent. Even for a 1-yr average depiction, it can be readily seen that the pressure change signal is tied to the Antarctic topography as shown by Parish and Bromwich (1997).

Adjacent to the Antarctic coastal margin is the circumpolar trough of low pressure that is found throughout the year. The trough represents the mean position of the frequent cyclonic activity along the margin of the continent (e.g., Schwerdtfeger 1984; King and Turner 1997; Bromwich and Parish 1998). Daily analyses and satellite imagery clearly depict the strong cyclonic nature of the baroclinic zone to the north of the continent. Most cyclones have centers that are on average several hundred kilometers north of the continental coastline in response to the Antarctic coastal ice escarpment, which rises above $2000 \mathrm{~m}$ within $200 \mathrm{~km}$ of the coast along East Antarctica. The ice sheet serves as a formidable barrier to the southward-moving air in the lowest

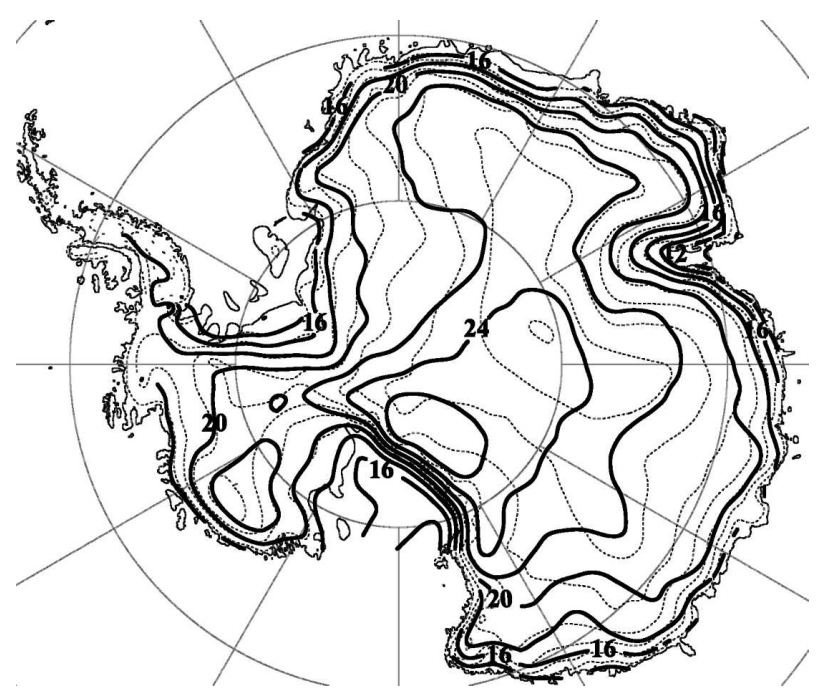

FIG. 11. Mean monthly surface pressure difference of December minus August 2003 from the AMPS archive.

levels of the atmosphere. Traditionally the circumpolar trough was thought to be a region of synoptic-scale cyclone maturity and decay (e.g., Streten and Troup 1973). However, the advent of high-resolution satellite imagery, and in the Ross Sea sector, the presence of an extensive array of automatic weather stations, has led to the realization that the trough is an active area of cyclone formation (e.g., Turner et al. 1998); activity on the mesoscale is especially pronounced in conjunction with the low-level baroclinic zones associated with the offshore propagation of katabatic winds from confluence zones (Figs. 2 and 3; Carrasco et al. 2003).

The low-level airflow off the Antarctic continent such as shown in Fig. 3 is also a factor in the establishment of the easterly wind regime at the surface. As noted by Schwerdtfeger (1984), the adjustment of the low-level winds that move northward from Antarctica serves to reinforce the easterly wind regime. Figure 12a depicts the mean sea level pressures and streamlines of the wind at the lowest sigma level from the $90-\mathrm{km}$ AMPS archive for the June 2003-May 2004 period. The band of easterlies appears to be $200-300 \mathrm{~km}$ in extent from the Antarctic coastline, scaling with the Rossby radius of deformation for the katabatic outflow. Observations of the low-level airflow in the coastal margin of Antarctica indicate that circumpolar easterlies are strongest adjacent to the coast and decrease to the north, eventually reversing to westerlies to the north of the circumpolar trough. The strongest easterly winds are found at the surface and decrease rapidly with height, similar to the continental wind regime. As an example, Fig. 12b illustrates vertical profiles of the zonal component of the wind from the $90-\mathrm{km}$ resolution 


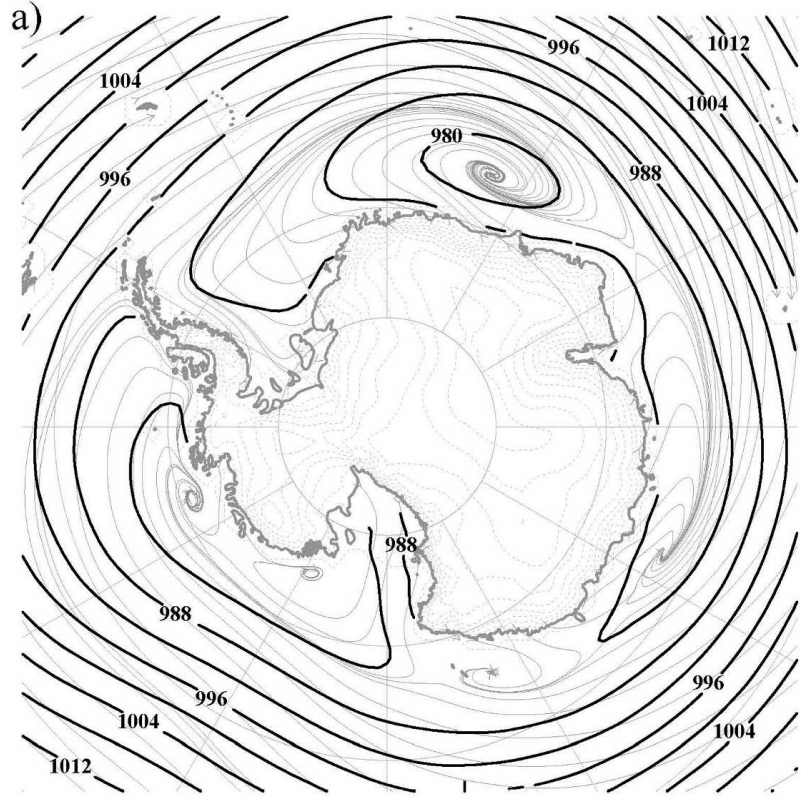

b)

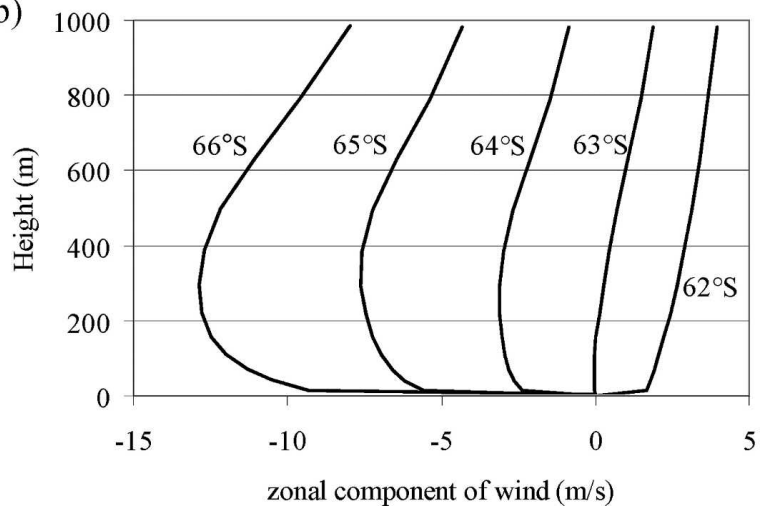

FIG. 12. (a) Mean sea level pressures (dark, solid lines; hPa) and streamlines (light, solid lines) of the wind field at $\sigma=0.9983$ (approximately $13 \mathrm{~m} \mathrm{AGL)} \mathrm{to} \mathrm{the} \mathrm{north} \mathrm{of} \mathrm{the} \mathrm{Antarctic} \mathrm{conti-}$ nent. (b) Vertical profiles of the zonal component of the wind in the lowest $1000 \mathrm{~m}$ to the north of Antarctica along $90^{\circ} \mathrm{E}$ from the 90-km resolution June 2003-May 2004 AMPS archive.

AMPS archive at $1^{\circ}$ increments from the coastline along $90^{\circ} \mathrm{E}$, which is representative of the East Antarctic sector. Wind profiles nearest the continent have a jetlike structure with maximum wind speeds several hundred meters above the surface. Significant adjustment of the continental flows occurs as the drainage flows move beyond the terminal ice slopes, moving in a pseudoinertial circle such that the wind regime is primarily easterly within a few kilometers of the coast.

As noted by Goodrick et al. (1998), surface stress induced by the wind field plays an important role in the development of ocean currents adjacent to the continent. Near the coast of the continent, westwarddirected surface currents exist that are in response to the easterly wind regime. It is known that the surface winds in the coastal margin of Antarctica have a profound effect on the sea ice concentration as well as vertical circulations within the ocean. Open leads and polynyas are common features associated with strong low-level winds, especially along the northern edge of the Ross Ice Shelf just to the west of $180^{\circ} \mathrm{E}$ (e.g., Bromwich et al. 1998), and are key areas for the generation of dense shelf water as a result of brine rejection during ice formation. Because the net transport in a vertical column of ocean is to the left of the wind in the Southern Hemisphere due to Coriolis effects, an easterly wind is associated with oceanic transport to the south. Downwelling must take place right at the coastline with upwelling, associated with the decay of the easterly wind, situated offshore. Goodrick et al. (1998) conclude that the low-level easterly wind regime adjacent to the continental periphery increases the upwelling volume by $70 \%$ over that produced by the westerly winds alone.

\section{Summary}

Dynamics of the airflow over the Antarctic continent are reasonably well understood. Winds are primarily controlled by the topographic slope and orientation of the underlying ice sheets. The wind field reflects the influence of katabatic drainage in response to diabatic cooling of the ice slopes as well as through the adjusted large-scale horizontal pressure gradients, established in part by the contrast between the cold continental ice surface and warmer ocean surface to the north.

Real-time simulations performed using the 30 - and 90- $\mathrm{km}$ resolution AMPS model for the 1-yr period of June 2003-May 2004 have been used to infer the mean circulation over the Antarctic continent. Streamline analyses from the AMPS $30-\mathrm{km}$ archive show strong topographic influence in the lowest levels of the atmosphere, confirming the earlier surface streamline depiction of Parish and Bromwich (1987). Effects of the terrain extend nearly $2 \mathrm{~km}$ above the surface as is evidenced by streamlines that parallel the broad ice terrain, suggesting that the resulting flows cannot merely be explained as katabatic phenomena. Winds over the continent are enhanced along confluence zones, regions where drainage currents converge as they move from atop the high interior of the ice sheet, and where maximum mean annual wind speeds in the lowest $100 \mathrm{~m}$ are in excess of $20 \mathrm{~m} \mathrm{~s}^{-1}$. Such zones also mark areas of concentrated northward mass fluxes. Cyclonic vorticity becomes established in the upper troposphere in response to the horizontal temperature gradients associated with the cold, sloping ice conti- 
nent. Negligible seasonal changes in the streamline patterns are found at low levels, although maximum wintertime wind speeds are reduced by $50 \%$ during summer.

Implications of the low-level wind regime over the Antarctic continent are profound. Northward transports of mass away from the continent are focused along confluence zones, being constrained by the orography. A thermally direct circulation results from the pattern of low-level outflow from Antarctica. Broad subsidence occurs over the continent and rising motion is found over the ocean adjacent to the continental coastline. There appears to be a relationship between the low-level continental flows and the circumpolar easterly circulation about the Antarctic periphery. Adjustment of the drainage flows off the continent occurs just north of the coastline. This marks the southern extent of the circumpolar trough and so there is a link between the low-level flows and cyclone development in the coastal margin.

The Southern (Hemisphere) Annular Mode (SAM; Thompson and Wallace 2000) is the dominant mode of circulation variability in the mid- and higher latitudes of the Southern Hemisphere on daily to interannual time scales (Baldwin 2001; Kidson 1999) and reflects changes in the circumpolar westerlies around Antarctica. It arises from an interaction between the westerly circulation and the oceanic cyclonic eddies (e.g., Lorenz and Hartmann 2001). Associated with the westerly changes are mass transports in the polar direct cell to support the altered zonal circulation (e.g., Kuroda 2005). Parish and Cassano (2003) and van den Broeke and van Lipzig (2003) note that the Antarctic surface winds are forced by both the diabatic cooling of nearsurface air and the terrain-forced blocking of the synoptic-scale free atmospheric flow. It will be important in the future to rationalize these two views of the forcing of the polar direct cell over Antarctica and to understand the feedback of this circulation on the SAM as a result of modifying the high-latitude baroclinicity.

Acknowledgments. This research was supported in part by the National Science Foundation Office of Polar Programs via Grant OPP-0229337 to T. Parish and UCAR Subcontract SO1-22961 to D. Bromwich.

\section{REFERENCES}

Adams, N., 2005: Identifying the characteristics of strong southerly wind events at Casey Station in East Antarctica using a numerical weather prediction system. Mon. Wea. Rev., 133, 3548-3561.

Baldwin, M. P., 2001: Annular modes in global daily surface pressure. Geophys. Res. Lett., 28, 4115-4118.
Ball, F. K., 1960: Winds on the ice slopes of Antarctica. Antarctic Meteorology, Proceedings of the Symposium in Melbourne, 1959, Pergamon, 9-16.

Bromwich, D. H., and T. R. Parish, 1998: Meteorology of the Antarctic. Meteorology of the Southern Hemisphere, Meteor. Monogr., No. 49, Amer. Meteor. Soc., 175-200.

- Z. Liu, A. N. Rogers, and M. L. Van Woert, 1998: Winter atmospheric forcing of the Ross Sea polynya. Ocean, Ice and Atmosphere: Interactions at the Antarctic Continental Margin, S. S. Jacobs and R. F. Weiss, Eds., Antarctic Research Series, Vol. 75, Amer. Geophys. Union, 101-133.

_ , J. J. Cassano, T. Klein, G. Heinemann, K. M. Hines, K. Steffen, and J. E. Box, 2001: Mesoscale modeling of katabatic winds over Greenland with the Polar MM5. Mon. Wea. Rev., 129, 2290-2309.

_, A. J. Monaghan, J. G. Powers, J. J. Cassano, H.-L. Wei, Y.-H. Kuo, and A. Pellegrini, 2003: Antarctic Mesoscale Prediction System (AMPS): A case study from the 2000-01 field season. Mon. Wea. Rev., 131, 412-434.

— - — K. W. Manning, and J. G. Powers, 2005: Real-time forecasting for the Antarctic: An evaluation of the Antarctic Mesoscale Prediction System (AMPS). Mon. Wea. Rev., 133, 579-603.

Carrasco, J. F., D. H. Bromwich, and A. J. Monaghan, 2003: Distribution and characteristics of mesoscale cyclones in the Antarctic: Ross Sea east to the Weddell Sea. Mon. Wea. Rev., 131, 289-301.

Cassano, J. J., J. E. Box, D. H. Bromwich, L. Li, and K. Steffen, 2001: Evaluation of Polar MM5 simulations of Greenland's atmospheric circulation. J. Geophys. Res., 106, 33 867-33 889.

Court, A., 1951: Antarctic meteorology. Compendium of Meteorology, T. F. Malone, Ed., Amer. Meteor. Soc., 917-941.

Gallée, H., P. Pettré, and G. Schayes, 1996: Sudden cessation of katabatic wind in Adélie Land, Antarctica. J. Appl. Meteor., 35, 1142-1152.

Goodrick, S. L., R. T. McNider, and W. W. Schroeder, 1998: On the interaction of the katabatic-land-sea wind system of Antarctica with the high latitude Southern Ocean. Ocean, Ice and Atmosphere: Interactions at the Antarctic Continental Margin, S. S. Jacobs and R. F. Weiss, Eds., Antarctic Research Series, Vol. 75, Amer. Geophys. Union, 51-65.

Guo, Z., D. H. Bromwich, and J. J. Cassano, 2003: Evaluation of Polar MM5 simulations of Antarctic atmospheric circulation. Mon. Wea. Rev., 131, 384-411.

Heinemann, G., 1997: Idealized simulations of the Antarctic katabatic wind system with a three-dimensional mesoscale model. J. Geophys. Res., 102, 13 825-13 834.

Hines, K. M., D. H. Bromwich, and T. R. Parish, 1995: A mesoscale modeling study of the atmospheric circulation of high southern latitudes. Mon. Wea. Rev., 123, 1146-1165.

Keller, L. M., G. A. Weidner, and C. R. Stearns, 1994: Antarctic automatic weather station data for the calendar year 1992. Department of Atmospheric and Oceanic Sciences, University of Wisconsin-Madison, 356 pp. [Available from the Department of Atmospheric and Oceanic Sciences, University of Wisconsin-Madison, Madison, WI 53706.]

Kidson, J. W., 1999: Principal modes of Southern Hemisphere low-frequency variability obtained from NCEP-NCAR reanalyses. J. Climate, 12, 2808-2830.

King, J. C., and J. Turner, 1997: Antarctic Meteorology and Climatology. Cambridge University Press, 409 pp.

Kuroda, Y., 2005: Meridional circulation and surface pressure 
change associated with the Southern Annular Mode: Comparison with the Arctic Oscillation. J. Geophys. Res., 110, D18106, doi:10.1029/2005JD005860.

Lorenz, D. J., and D. L. Hartmann, 2001: Eddy-zonal flow feedback in the Southern Hemisphere. J. Atmos. Sci., 58, 33123327.

Mather, K. B., and G. S. Miller, 1966: Wind drainage off the high plateau of eastern Antarctica. Nature, 209, 281-284.

Meehl, G. A., 1991: A reexamination of the mechanism of the semiannual oscillation in the Southern Hemisphere. J. Climate, 4, 911-926.

Monaghan, A. J., D. H. Bromwich, H. Wei, A. M. Cayette, J. G. Powers, Y. H. Kuo, and M. Lazzara, 2003: Performance of weather forecast models in the rescue of Dr. Ronald Shemenski from the South Pole in April 2001. Wea. Forecasting, 18, $142-160$.

Parish, T. R., and D. H. Bromwich, 1987: The surface windfield over the Antarctic ice sheets. Nature, 328, 51-54.

— winds. Mon. Wea. Rev., 115, 2214-2226.

- , and D. H. Bromwich, 1991: Continental-scale simulation of the Antarctic katabatic wind regime. J. Climate, 4, 135-146.

- , and 1997: On the forcing of seasonal changes in surface pressure over Antarctica. J. Geophys. Res., 102, $13785-$ 13792.

_, and J. J. Cassano, 2003: The role of katabatic winds on the Antarctic surface wind regime. Mon. Wea. Rev., 131, 317333

- and R. Walker, 2006: A re-examination of the winds of Adélie Land, Antarctica. Aust. Meteor. Mag., 55, 105-117.

Powers, J. G., A. J. Monaghan, A. M. Cayette, D. H. Bromwich, Y.-H. Kuo, and K. W. Manning, 2003: Real-time mesoscale modeling over Antarctica: The Antarctic Mesoscale Prediction System. Bull. Amer. Meteor. Soc., 84, 1533-1545.

Schwerdtfeger, W., 1984: Weather and Climate of the Antarctic. Elsevier, $261 \mathrm{pp}$.

Streten, N. A., and A. J. Troup, 1973: A synoptic climatology of satellite observed cloud vortices over the Southern Hemisphere. Quart. J. Roy. Meteor. Soc., 99, 56-72.

Thompson, D. W., and J. M. Wallace, 2000: Annular modes in the extratropical circulation. Part I: Month-to-month variability. J. Climate, 13, 1000-1016.

Turner, J., G. J. Marshall, and T. Lachlan-Cope, 1998: Analysis of synoptic-scale low pressure systems within the Antarctic Peninsula sector of the circumpolar trough. Int. J. Climatol., 18, 253-280.

van den Broeke, M. R., and N. P. M. van Lipzig, 2003: Factors controlling the near-surface wind field in Antarctica. Mon. Wea. Rev., 131, 733-743.

van Lipzig, N. P. M., J. Turner, S. R. Colwell, and M. R. van den Broeke, 2004: The near-surface wind field over the Antarctic continent. Int. J. Climatol., 24, 1973-1982. 